\title{
Thin terrestrial sediment deposits on intertidal sandflats: effects on pore-water solutes and juvenile bivalve burial behaviour
}

\author{
A. Hohaia ${ }^{1}$, K. Vopel $^{1}$, and C. A. Pilditch ${ }^{2}$ \\ ${ }^{1}$ Auckland University of Technology, Institute for Applied Ecology New Zealand, Private Bag 92006, Auckland 1142, \\ New Zealand \\ ${ }^{2}$ University of Waikato, Department of Biological Sciences, Private Bag 3105, Hamilton 3240, New Zealand
}

Correspondence to: K. Vopel (kvopel@aut.ac.nz)

Received: 14 August 2013 - Published in Biogeosciences Discuss.: 9 September 2013

Revised: 21 January 2014 - Accepted: 4 March 2014 - Published: 22 April 2014

\begin{abstract}
Nearshore zones experience increased sedimentation due to coastal development and enhanced loads of fine terrestrial sediment (hereafter, TS) in river waters. Deposition of TS can alter seabed biogeochemical processes but the effects on benthic ecosystem functioning are unknown. The results of a past experiment with defaunated, intertidal sediment suggest that a decrease in the oxygenation of this sediment by a thin (mm) TS deposit causes substrate rejection (refusal to bury) by post-settlement juvenile recruits of the tellinid bivalve Macomona liliana. We further examined this behaviour, asking if such deposits negatively affect burial when applied to intertidal sediment that is oxygenated by bioturbation (C) or depleted of dead and living organic matter (D). We observed recruits on the surface of four treatments: C, D, and the same sediments to which we added a 1.7-1.9 mm layer of TS (CTS, DTS). The TS deposit decreased the oxygenation and the $\mathrm{pH}$ of the underlying intertidal sediment (CTS) confirming previous results, but significantly increased but not decreased the probability of burial, irrespectively of treatment. Juveniles more likely buried into $\mathrm{C}$ than into D. The mechanism that caused previously observed substrate rejection by post-settlement juvenile $M$. liliana remains unclear but our results suggest that contact of the recruits with the TS deposit does not cause substrate rejection. We now hypothesise that conditioning of sediment by bioturbation can mediate negative effects of TS deposits on the recruits' burial behaviour.
\end{abstract}

\section{Introduction}

Changes in land use, a rising sea level, and extreme rainfall events increase the supply of terrestrial sediment (hereafter, TS) to coastal habitats, either as suspended particles via waterways or directly from landslides (Milliman and Meade, 1983; Thrush et al., 2004). The suspended TS eventually settles, forming a deposit on the surface of the softsediment seafloor. This deposit - until reworked by benthic fauna or suspended by flow - alters functions of the sedimentary ecosystem. It affects benthic organic carbon decomposition and production by impeding the sediment-seawater exchange of reactive solutes, altering the behaviour of benthic species and associated solute reaction dynamics or, depending on the scale of the deposit, the composition of the benthic species assemblage (Thrush et al., 2003; Cummings et al., 2009; Woodin et al., 2012).

For centimetre-thick TS deposits, experiments in New Zealand estuaries have documented changes in benthic faunal assemblages due to migration, mortality, and recruitment failure (Norkko et al., 2002; Cummings et al., 2003; Lohrer et al., 2004). More commonly, TS deposits form thin, millimetre-thick layers but these may still affect the sedimentary ecosystem by modifying the burial behaviour of juvenile recruits and the sediment uptake and release of reactive solutes (Cummings et al., 2009). The effect of thin TS deposits on the exchange of reactive solutes will be a function of macrofaunal activity, which is influenced by how the deposit formed. For example, compare these two scenarios: suspended TS may form a millimetre-thick deposit on the surface of coastal sediment already colonised by burrowing 
macrofauna. Such a deposit will impede the diffusive solute exchange across the visible sediment surface, but it may not affect solute exchange across subsurface linings of macrofaunal burrows. In contrast, a centimetre-thick deposit will kill and/or remove the fauna of the sediment and over time, tidal currents and waves may erode it down to a thin millimetrethick layer. In such a case, the deposit covers the entire sediment-seawater exchange surface and so affects all solute exchange.

For the latter scenario (i.e. thin TS deposit on defaunated sediment), Cummings et al. (2009) suggest a link between the TS-induced decrease in the oxygenation of the underlying sediment and substrate rejection by post-settlement juvenile recruits of the tellinid bivalve Macomona liliana (Iredale, 1915). Such rejection is of interest because it affects the species' dispersal. In soft-sediment systems in particular, dispersal of post-settlement juveniles significantly contributes to local (within estuary) population connectivity and the regulation and organisation of benthic communities (Dayton et al., 1994; Norkko et al., 2001; Valanko et al., 2010). For example, the potential dispersal of M. liliana post-settlement juveniles on intertidal sandflats is in the order of kilometres per tidal cycle (Petuha et al., 2006), which is similar to the realised dispersal distances of many benthic coastal species with a pelagic larval stage (see Shanks (2009) for a discussion).

The results by Cummings et al. (2009) support the hypothesis that benthic solute transport and reaction processes affect the behaviour of juvenile recruits (see also Woodin et al., 1995; Woodin, 1998; and Marinelli and Woodin, 2002, 2004), specifically, that juvenile recruits at the surface of the deposit probe reduced products of the microbial decomposition of organic matter to assess the suitability of the underlying sediment. If juvenile recruits reject the TS deposit in response to contact with reduced solutes due to a depositinduced decrease in the oxygenation of the underlying sediment, but not in response to contact with TS, then this behaviour should be a function of the sediments' potential to accumulate reduced solutes. A TS deposit over less reactive sediment (less organic matter) should not cause a rejection. Similarly, a TS deposit over reactive sediment that is ventilated by tube-dwelling macrofauna should also not cause a rejection.

Here we extend the study by Cummings et al. (2009), testing whether deposits of freshly suspended TS negatively affect burial of juvenile recruits (i) in the presence of macroinfauna and (ii) in the absence of organic matter in the underlying sediment. To do so, we observed the behaviour of post-settlement juvenile M. liliana, the bivalve species used by Cummings et al. (2009), on the surface of TS deposited over (i) undisturbed, bioturbated intertidal sediment and (ii) intertidal sediment from which we removed dead and living organic matter by combustion (hereafter, depleted sediment). Assuming that the juveniles are responding to contact with reduced solutes diffusing from the pore water of

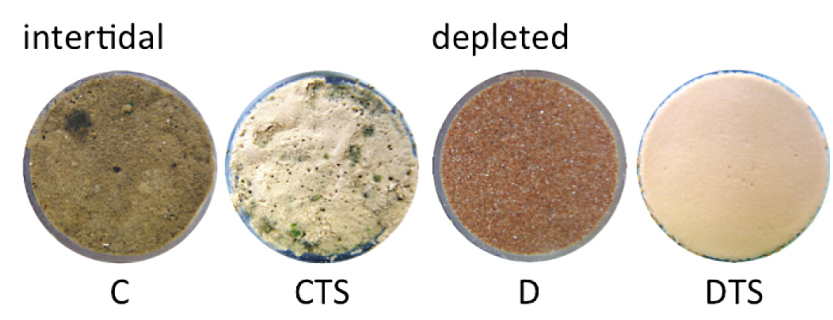

Fig. 1. Surface photographs of four sediment core treatments after $18 \mathrm{~h}$ : (C) intact intertidal sediment, (CTS) intertidal sediment covered with TS, (D) organic-matter depleted sediment, and (DTS) depleted sediment covered with TS. Core diameter $=5 \mathrm{~cm}$.

the sediment underlying the TS deposit and not to contact with the TS (sensu Cummings et al., 2009), we predicted that burial into bare depleted sediment and depleted sediment to which a layer of TS was added would not differ because the TS layer does not build up reduced solutes in the underlying sediment. We also predicted that burial into bioturbated sediment and bioturbated sediment to which a TS layer was added would not differ because the resident macrofauna oxygenates the sediment enough to offset TS induced accumulation of reduced solutes. If contact with TS is the driver then in both sediments (bioturbated and depleted) the TS treatments should have a lower burial rate.

\section{Material and methods}

\subsection{Experimental design}

We conducted five replicate experiments (hereafter, Runs) in a recirculating seawater flume to investigate how deposits of TS on the surface of two types of intertidal sediment affect pore-water solute concentrations and the burial behaviour of post-settlement juvenile $M$. liliana. Because only one flume was available, we conducted the Runs consecutively in May and June 2011; each Run lasted two days (Table 1).

On the first day of each Run, we inserted two cores of each sediment type into the flume: intact natural intertidal sediment (hereafter, intertidal), and intertidal sediment from which living and dead organic matter was removed by combustion (hereafter, depleted). We covered the surface of one core of each sediment type with a thin layer of TS. That is, each Run tested four sediment treatments: intertidal sediment (C), depleted sediment (D), TS over intertidal sediment (CTS) and TS over depleted sediment (DTS; Table 1, Fig. 1).

On the second day of each Run, after an $18 \mathrm{~h}$ acclimation of the sediment to unidirectional flume flow (free stream flow velocity $\sim 2.4 \mathrm{~cm} \mathrm{~s}^{-1}$ ), we recorded either five $\mathrm{O}_{2}$ (Run 1,2 , 3 ), two oxidation-reduction potential (Eh, Run 4), or two pH (Run 5) microprofiles in each sediment core (Table 1). After profiling, we stopped the flume flow and released twenty post-settlement juvenile individuals of $M$. liliana from one 
Table 1. Date of sediment collection in 2011, type and number of pore water microprofiles measured in each core, maximum and minimum flume seawater temperature during the Runs and allocation of sediment core treatments to each of the four core positions.

\begin{tabular}{cllcclllll}
\hline & & Profiles & \multicolumn{3}{c}{ Temp. $\left({ }^{\circ} \mathrm{C}\right)$} & \multicolumn{4}{c}{ Core position (no. of juveniles) } \\
Run & Date & $(n)$ & $\mathrm{Max}$ & $\mathrm{Min}$ & 1 & 2 & 3 & 4 \\
\hline 1 & 24 May & $\mathrm{O}_{2}(5)$ & 18.4 & 16.9 & $\mathrm{CTS}$ & $\mathrm{DTS}$ & $\mathrm{C}$ & $\mathrm{D}$ \\
2 & 26 May & $\mathrm{O}_{2}(5)$ & 20.0 & 18.9 & $\mathrm{D}$ & $\mathrm{CTS}$ & $\mathrm{DTS}$ & $\mathrm{C}$ \\
3 & 31 May & $\mathrm{O}_{2}(5)$ & 18.3 & 16.6 & $\mathrm{C}$ & $\mathrm{D}$ & $\mathrm{CTS}$ & $\mathrm{DTS}$ \\
4 & 2 June & $\mathrm{Eh}(2)$ & 18.2 & 16.9 & DTS & $\mathrm{C}$ & $\mathrm{D}$ & $\mathrm{CTS}$ \\
5 & 10 June & $\mathrm{pH}(2)$ & - & - & $\mathrm{CTS}$ & $\mathrm{DTS}$ & $\mathrm{C}$ & $\mathrm{D}$ \\
\hline
\end{tabular}

pipette placed above each of four sediment cores so that they drifted onto the sediment surface. We initiated the flow and observed their burial behaviour over the following $4 \mathrm{~h}$.

\subsection{Sediments and bivalves}

We collected intertidal sediment and post-settlement juvenile M. liliana concurrently from Tauranga Harbour, a large tidal inlet on the northeast coast of the North Island, New Zealand. The collection took place at a sheltered mid-intertidal sandflat $80 \mathrm{~m}$ east of Tuapiro Channel in the northern basin of the harbour $\left(37^{\circ} 29^{\prime} 29^{\prime \prime} \mathrm{S}, 175^{\circ} 56^{\prime} 51^{\prime \prime} \mathrm{E}\right)$ on the first morning of each Run within $1 \mathrm{~h}$ either side of low tide. Fine sands (median grain diameter $\sim 120-170 \mu \mathrm{m})$ with a low $(\sim 4$ $8 \%)$ silt/clay $(<63 \mu \mathrm{m})$ content characterise sediments at the collection site. The clam Austrovenus stutchburyi and $M$. liliana dominate macrofaunal biomass but numerically the most important taxa are polychaetes $\left(\sim 34\right.$ per $\left.0.01 \mathrm{~m}^{2}\right)$ followed by bivalves $\left(\sim 13\right.$ per $\left.0.01 \mathrm{~m}^{2}\right)$ and amphipods $(\sim 10$ per $0.01 \mathrm{~m}^{2}$ ) (Lelieveld et al., 2004; Pratt et al., 2014).

To collect juvenile $M$. liliana, we washed surface sediment with seawater on a $0.5 \mathrm{~mm}$ mesh and placed all retained material into one seawater-filled bag. In the laboratory, we sorted this material under a dissecting microscope, placing 20 post-settlement juvenile $M$. liliana in each of four containers filled with aerated, artificial seawater. Their shell length was $1.6 \pm 0.2 \mathrm{~mm}($ mean $\pm 1 \mathrm{SD}, n=400, \max =2.3 \mathrm{~mm}$, $\min =1.1 \mathrm{~mm}$ ).

To collect intertidal sediment, we inserted one acrylic tube (inner diameter $=5.3 \mathrm{~cm}$ ) $\sim 10 \mathrm{~cm}$ into the sandflat at each of six sites randomly defined with Cartesian co-ordinates within a $10 \mathrm{~m}$-diameter area. Stoppers placed at the bottom and the top of each tube enclosed the sediment core. Of these six sediment cores, we inserted two into the flume and froze one for later analyses of sediment water content, organic matter content, and grain size distribution. To make cores of organicmatter depleted sediment, intertidal sediment was combusted in a muffle furnace at $450^{\circ} \mathrm{C}$ for $6 \mathrm{~h}$ to remove organic carbon, and then added to acrylic tubes filled with artificial seawater.

We obtained TS from a landslide at Hahei Beach, Coromandel, and suspended about $100 \mathrm{~g}$ of this sediment in $100 \mathrm{~mL}$ artificial seawater on the first day of each Run. We poured this suspension through a $250 \mu \mathrm{m}$ mesh to remove large particles and then used $15 \mathrm{~mL}$ to create a $1-2 \mathrm{~mm}$-thick deposit on the surface of each of two cores in the flume. Aliquots of $10 \mathrm{~mL}$ were used for particle size analyses.

We measured particle size, water content, and organic matter content of the homogenised top $5 \mathrm{~cm}$ of the intertidal sediment following Giere (1993). This sediment was poorly sorted fine and very fine sand (median particle diameter $114 \mu \mathrm{m})$. Depleted sediment was moderately sorted medium sand (median particle diameter $330 \mu \mathrm{m})$. Mud (< $63 \mu \mathrm{m}$ ), water, and organic matter contents were higher in intertidal sediment $(13.4,27.1$, and $2.2 \%$, respectively) than in depleted sediment $(2.4,19.4$, and $0.4 \%$, respectively). The median diameter of the well or moderately well sorted particles in the TS suspension, determined with a Malvern Mastersizer-2000, ranged from 87 to $98 \mu \mathrm{m}$. The mud content of this sediment ranged from 41 to $53 \%$.

\subsection{Seawater flume environment}

The flume consists of a $7.23 \mathrm{~m}$ long, $50 \mathrm{~cm}$ wide, and $50 \mathrm{~cm}$ deep acrylic channel with a $40 \mathrm{~cm}$-diameter return pipe that runs beneath the channel. An impeller in the descending arm of the return pipe regulates flow speed via a variable-speed motor. Four holes in the floor of the working section $(550 \mathrm{~cm}$ downstream from the flume entrance) allowed the insertion of tubes containing the sediment cores. These holes were evenly spaced along a line perpendicular to the raceway and confined to the central $33 \mathrm{~cm}$ in the cross-stream direction.

We inserted the sediment-filled tubes into the flume through its bottom plate and then filled the flume with artificial seawater to $19 \mathrm{~cm}$. Thereafter, we raised the sediment inside the four tubes with a precision extruder so that their surfaces were flush with the flume floor. We then lowered the surfaces of those two cores that required a surface deposit of TS (Table 1) by $\sim 1-2 \mathrm{~mm}$ and applied the deposit.

To apply a deposit of TS, we placed one PVC tube (inner diameter $=6.5 \mathrm{~cm}$ ) above each sediment core in the flume. The PVC tubes confined the suspension of TS to the seawater directly above the sediment core, and prevented deposition on to the bottom of the flume and the neighbouring sediment cores. We added the suspension to the seawater inside the two PVC tubes above the receiving cores and waited $30 \mathrm{~min}$ 
for particles to settle. For the remaining two cores, seawater was added to the PVC tubes instead of the TS suspension. All PVC tubes were then carefully removed, the flow was started (free stream velocity $=2.41 \mathrm{~cm} \mathrm{~s}^{-1}$ ) and the flume was left running overnight.

Flume seawater temperature, salinity, and $\mathrm{O}_{2}$ content, measured with a multiparameter sonde (model 6600V2-4, YSI Inc.) submerged downstream of the flume working section, ranged from 17 to $20^{\circ} \mathrm{C}, 32.7$ to 32.9 , and 90 to $94 \%$ saturation. The intensity of the photosynthetically active radiation incident from the ceiling lights of the laboratory was $22 \mu \mathrm{mol}$ photons $\mathrm{m}^{-2} \mathrm{~s}^{-1}$ (LI-192 Underwater Quantum Sensor, LI-COR). The ceiling lights were off from 20:00 to 07:00 h.

Four $10 \mathrm{~min}$ time series measurements with a Sontek 10 $\mathrm{MHz}$ acoustic Doppler Velocimeter revealed that the flow velocity of the seawater in the boundary layer $(0-18 \mathrm{~mm})$ above flume bottom was highest in core position $1\left(1.9 \mathrm{~cm} \mathrm{~s}^{-1}\right)$ and gradually decreased towards core position $4\left(1.4 \mathrm{~cm} \mathrm{~s}^{-1}\right)$. To account for this variation, we rotated the position of each of the four core treatments across Runs (Table 1).

\subsection{Pore-water profiling}

We measured vertical microprofiles of pore-water $\mathrm{O}_{2}$ concentration (hereafter, $\left[\mathrm{O}_{2}\right]$ ), $\mathrm{pH}$, and Eh with Unisense hardand software at a resolution of $0.1 \mathrm{~mm}\left(\mathrm{O}_{2}\right), 0.2(\mathrm{pH})$, and $0.5 \mathrm{~mm}(\mathrm{Eh})$ normal to the sediment surface from a position in the flowing seawater above the diffusive boundary layer ( $\sim 2 \mathrm{~mm}$ above the sediment surface, hereafter, DBL) to a maximum depth of $5.5 \mathrm{~mm}$. We calibrated the Unisense microelectrodes once a day before commencement of a measurement series, following the instructions of the manufacturer (see www.unisense.com).

\subsection{Bivalve behaviour and surface activity}

To record the burial behaviour of juvenile M. liliana, we took one digital underwater photograph of the surface of each sediment core per minute for the first $10 \mathrm{~min}$ starting immediately after their placement. Thereafter, we took one photograph every hour until completion of the experiment. We used these photographs to count juveniles on the sediment surface 1, 10, and $240 \mathrm{~min}$ after their placement and to observe their behaviour. The photographs of the CTS treatment revealed counts and diameter of polychaete burrow openings, siphons, microphyte patches, and patches of black, subsurface sediment.

Based on the photographs, we quantified the following behaviours: immediate burial - the juvenile rested on one valve; the foot dug into the sediment anterior end first, so that the apex-siphonal end of the shell was protruding from the sediment. It continued to bury deeper so that the siphonal end was no longer protruding and completely buried within $3 \mathrm{~min}$. Delayed burial - the juvenile rested on one valve for
$>3 \mathrm{~min}$ before it buried as described above within $10 \mathrm{~min}$. Delayed search and burial - the juvenile rested on one valve for $>3 \mathrm{~min}$ before it orientated itself so that its apex was uppermost, with its anterior end in front and siphonal end behind. Using the foot, the juvenile crawled along the sediment surface, anterior end first. Its foot dug into the sediment anterior end first, with the apex-siphonal end protruding from the sediment. The juvenile completed burial within $10 \mathrm{~min}$. Emergence (see Cummings et al., 1993) - after complete burial, the juvenile resurfaced, anterior end foremost, with its valves slightly open and the foot brought close to the gape. The juvenile then moved upward until only its siphonal end remained embedded, toppled over, and came to rest on one valve. Drift - some juveniles that had buried into depleted sediment emerged to first crawl a distance on the sediment surface, stop, and then position their shells vertically. The juveniles then toppled onto one valve and skidded downstream with the apex of the shell facing upstream and left the core surface via byssus drifting. Subsurface search - a trace indicated that the juvenile had crawled below the surface of the sediment.

\subsection{Data analyses}

Two distinct changes in the slope of the $\mathrm{O}_{2}$ microprofiles indicated the position of the upper and lower boundaries of the TS deposits. These changes resulted from differences in $\mathrm{O}_{2}$ diffusivity between the deposit and the underlying sediment and overlying seawater. We estimated the sediment diffusive $\mathrm{O}_{2}$ uptake across the visible sediment surface (hereafter, DOU) from the slope of the $\left[\mathrm{O}_{2}\right]$ gradient in the DBL and the diffusion coefficient for $\mathrm{O}_{2}$.

Consistent with Roper and Hickey (1994), Cummings et al. (1996), and Cummings and Thrush (2004), we used the number of juveniles remaining on the sediment surface 10 min after their placement as a measure of the sediment acceptability. To predict the probability of juveniles to remain on the sediment surface after $10 \mathrm{~min}$, we used a logistic model (generalised linear model, binomial family, software $\mathrm{R})$. To retain all trials whatever the value of $n(n=18-20)$, the data were weighted with respect to $n$; larger values of $n$ constituted more statistically informative experiments. We viewed minor variation in flow velocity across the flume as a proxy for fluid mechanical environmental variability caused by variations in tidal flow velocity, turbulent intensity, etc.; this was done by considering results from each position as part of a statistical ensemble. With this assumption, different combinations of regressors were trialled. The trial revealed that the appropriate regressors were sediment type (intertidal and depleted) and the presence or absence of a TS deposit. We assumed that the few juveniles that left their sediment core in the course of the experiment did not interfere with the burrowing results of the other three cores. 
Table 2. Number and diameter (mean $\pm 1 \mathrm{SD}, \mathrm{mm}$ ) of burrow openings, number of siphons and green and black patches showing at the surface of a TS deposit overlying intertidal sediment (CTS) $4 \mathrm{~h}$ after application of the deposit.

\begin{tabular}{lccccc}
\hline & \multicolumn{5}{c}{ Experimental Run } \\
& 1 & 2 & 3 & 4 & 5 \\
\hline Burrow openings & 68 & 75 & 64 & 37 & 123 \\
Average diameter & $0.66 \pm 0.33$ & $0.51 \pm 0.23$ & $0.52 \pm 0.26$ & $0.46 \pm 0.23$ & $0.75 \pm 0.37$ \\
Minimum diameter & 0.19 & 0.15 & 0.08 & 0.16 & 0.15 \\
Maximum diameter & 1.68 & 1.21 & 1.46 & 1.27 & 1.63 \\
Siphons & 0 & 32 & 0 & 12 & 0 \\
Green patches & 2 & 3 & 4 & 3 & 0 \\
Black patches & 4 & 11 & 8 & 6 & 1 \\
\hline
\end{tabular}

\section{Results}

\subsection{Sediment surface structure and colour}

The brown surface of intertidal sediment showed millimetrescale topography (treatment $\mathrm{C}$ in Fig. 1). The orange surface of the TS overlying this sediment was smooth and free of disturbance immediately after its deposition. In as little as $30 \mathrm{~min}$, however, small openings of polychaete burrows (average diameter $0.5-0.8 \mathrm{~mm}$ ), siphons, traces, and patches of green microphytes (longest axis $15 \mathrm{~mm}$ ) appeared (Fig. 1, Table 2). On the following day, $4 \mathrm{~h}$ after placement of the juveniles, we counted 37 to 123 burrow openings per core. Up to four green patches ( $5 \mathrm{~mm}$ longest axis) and 32 siphons were present, and black, excavated sediment had buried small $\left(3 \mathrm{~cm}^{2}\right)$ patches of the deposit.

In contrast to intertidal sediment, the red-brown surface of depleted sediment was homogeneous and flat (D in Fig. 1) and the orange surface of the TS deposit overlying this sediment remained smooth and flat until the juveniles were placed (DTS in Fig. 1).

\subsection{Pore-water chemistry}

\subsubsection{Oxygenation}

On average, $\mathrm{O}_{2}$ penetrated intertidal sediment across the visible sediment surface 1.1 to $1.4 \mathrm{~mm}$ (Table 3; example profiles in Fig. 2). For all three Runs, application of a TS deposit (1.7-1.9 mm thick) decreased this penetration to 0.8 or $0.9 \mathrm{~mm}$. In contrast, the pore waters of TS-treated and bare depleted sediments contained dissolved $\mathrm{O}_{2}$ to at least $5 \mathrm{~mm}$ depth, the maximum depth measured.

The average DOU of the intertidal sediment ranged from 826 to $1161 \mu \mathrm{mol} \mathrm{m}{ }^{-2} \mathrm{~h}^{-1}$ (Table 3). Application of TS decreased this range to $591-695 \mu \mathrm{mol} \mathrm{m}^{-2} \mathrm{~h}^{-1}$. In contrast, deposition of TS onto the surface of depleted sediment had the opposite effect on DOU. For all three Runs, the mean DOU of the depleted sediment, ranging from 16 to $28 \mu \mathrm{mol} \mathrm{m}{ }^{-2} \mathrm{~h}^{-1}$, was lower than that of TS-covered depleted sediment $\left(46-71 \mu \mathrm{mol} \mathrm{m}^{-2} \mathrm{~h}^{-1}\right)$. We attribute this
Table 3. Average diffusive $\mathrm{O}_{2}$ uptake (DOU, mean $\pm 1 \mathrm{SD}, n=5$ ) across the visible sediment surface and $\mathrm{O}_{2}$ penetration depth (OPD, mean $\pm 1 \mathrm{SD}$ ) in bare intertidal (C) and depleted (D) sediments and deposit-underlying intertidal (CTS) and depleted (DTS) sediments. For CTS and DTS, OPD is the distances from the sediment-deposit to the oxic-anoxic boundary. The oxic-anoxic boundary in D and DTS was below $5 \mathrm{~mm}$ depth, the maximum depth measured.

\begin{tabular}{|c|c|c|c|}
\hline Run & Treatment & $\operatorname{DOU}\left(\mu \mathrm{mol} \mathrm{m}{ }^{-2} \mathrm{~h}^{-1}\right)$ & $\mathrm{OPD}(\mathrm{mm})$ \\
\hline \multirow[t]{2}{*}{1} & $\mathrm{C}$ & $1161 \pm 274$ & $1.1 \pm 0.1$ \\
\hline & CTS & $649 \pm 78$ & $0.8 \pm 0.2$ \\
\hline \multirow[t]{2}{*}{2} & $\mathrm{C}$ & $826 \pm 201$ & $1.4 \pm 0.3$ \\
\hline & CTS & $591 \pm 58$ & $0.9 \pm 0.2$ \\
\hline \multirow[t]{2}{*}{3} & $\mathrm{C}$ & $935 \pm 283$ & $1.2 \pm 0.1$ \\
\hline & CTS & $695 \pm 133$ & $0.8 \pm 0.2$ \\
\hline \multirow[t]{2}{*}{1} & $\mathrm{D}$ & $18 \pm 4$ & $>5$ \\
\hline & DTS & $71 \pm 7$ & $>5$ \\
\hline \multirow[t]{2}{*}{2} & $\mathrm{D}$ & $16 \pm 7$ & $>5$ \\
\hline & DTS & $46 \pm 16$ & $>5$ \\
\hline \multirow[t]{2}{*}{3} & $\mathrm{D}$ & $28 \pm 15$ & $>5$ \\
\hline & DTS & $63 \pm 10$ & $>5$ \\
\hline
\end{tabular}

difference to the $\mathrm{O}_{2}$ consumption of the TS deposit $(<$ $55 \mu \mathrm{mol} \mathrm{O}_{2} \mathrm{~m}^{-2} \mathrm{~h}^{-1}$ ).

\subsection{2 pH and Eh}

All pore-water $\mathrm{pH}$ profiles (with one exception) share common features: a steep decrease in $\mathrm{pH}$ to a minimum at some depth below the sediment surface followed by a brief increase and, in some profiles, stable pH at depth (Fig. 2). Depositing TS over intertidal sediment decreased the subsurface $\mathrm{pH}$ minimum. We observed a similar effect in the $\mathrm{pH}$ profiles of the depleted sediment, which showed less pronounced subsurface peaks at greater depths and higher $\mathrm{pH}$ at depths.

Inspection of our Eh profiles revealed a transition from oxidising to reducing pore water at $2-4 \mathrm{~mm}$ depth of the intertidal sediment (Fig. 2). The depth of this transition measured from the surface of the TS deposit increased by the thickness 

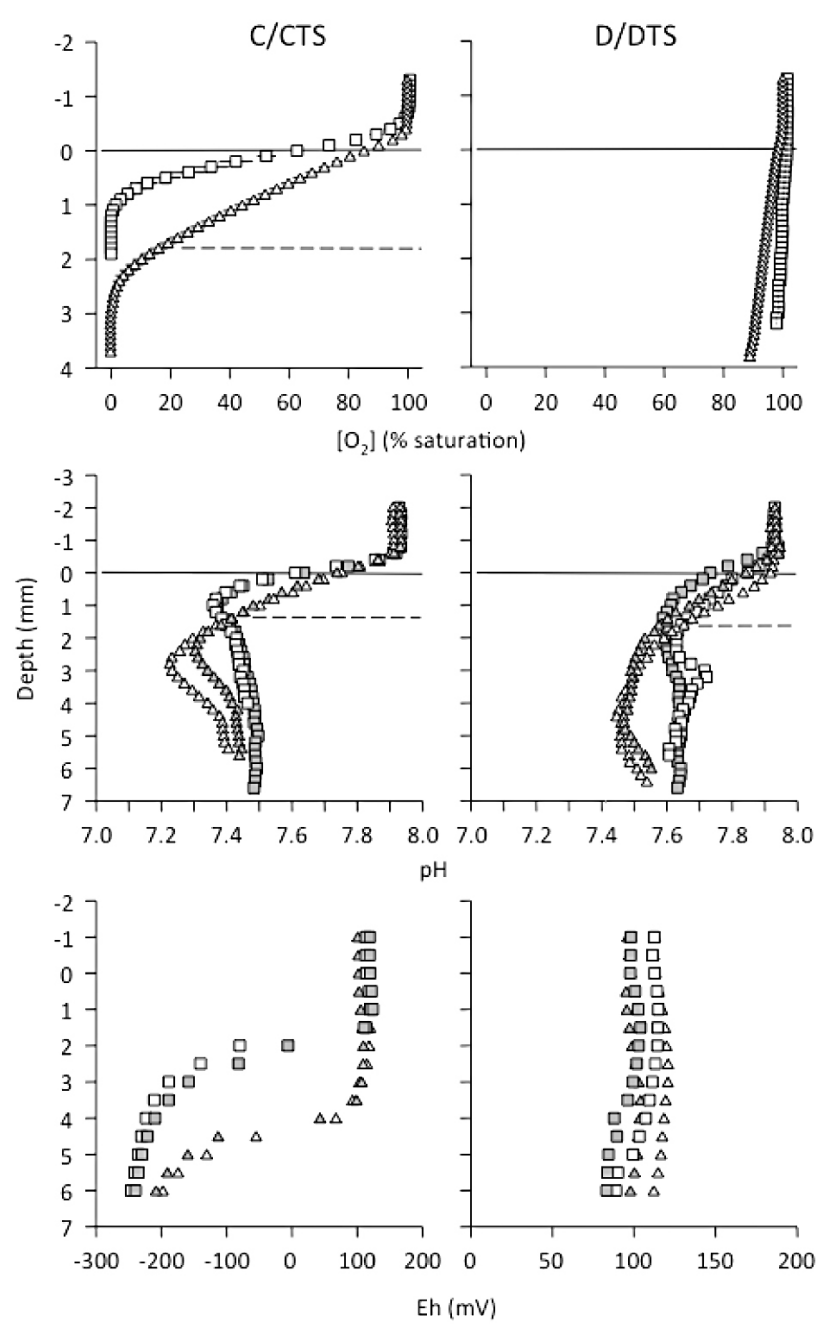

Fig. 2. Example mean pore-water $\mathrm{O}_{2}$ concentration microprofiles (mean $\pm 1 \mathrm{SD}, n=5$ ) and microprofiles of $\mathrm{pH}$ and oxidationreduction potential in intact intertidal (C/CTS, left panel) and organic-matter depleted intertidal sediment (D/DTS, right panel). Squares: untreated sediment surface; triangles: surface covered with a 1-2 mm-thick layer of TS. The solid lines indicate the sedimentwater interface and the dashed lines the boundary between the TSdeposit-underlying intertidal sediment. Open and grey symbols represent replicate profiles. C: untreated intertidal sediment; CTS: intertidal sediment covered with TS; and DTS: organic-matter depleted sediment covered with TS.

of the deposit. The Eh profiles in the depleted sediment indicated that the sediment was oxidised to the maximum depth measured.

\subsection{Macomona liliana}

In five instances, of the 20 post-settlement juveniles released in the bottom seawater, we counted only 18 or 19 individuals on the sediment surface immediately following their release. The missing juveniles either landed on the floor of the flume

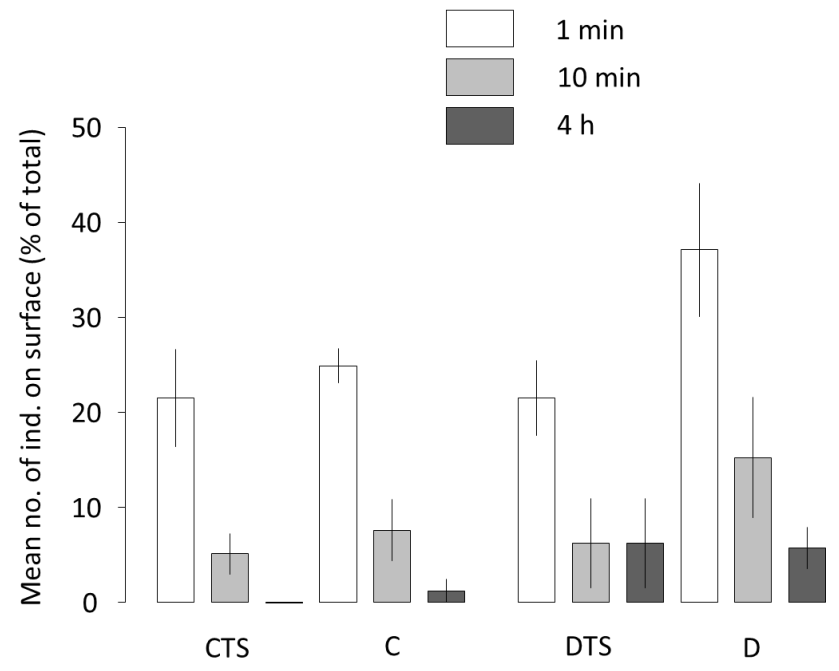

Fig. 3. Macomona liliana. Average number of post-settlement juveniles (mean $\pm 1 \mathrm{SD}, n=5$ ) remaining on the sediment surface after $1 \mathrm{~min}, 10 \mathrm{~min}$, and $4 \mathrm{~h}$ after placement expressed as a percentage of the total initially added (18-20 individuals). C: untreated intertidal sediment; CTS: intertidal sediment covered with TS; and DTS: organic-matter depleted sediment covered with TS.

Table 4. Macomona liliana. Behavioural response of postsettlement juveniles placed onto the surfaces of TS-treated and bare intertidal (CTS, C) and depleted (DTS, D) sediment. Data represent the number of individuals that exhibited the behaviour, a dash indicates that a behaviour was not observed.

\begin{tabular}{lcccc}
\hline Response & C & CTS & D & DTS \\
\hline Burial & & & & \\
$\quad$ Immediate burial & 90 & 91 & 76 & 87 \\
$\quad$ Delayed burial & 3 & 6 & 1 & 6 \\
$\quad$ Delayed search and burial & 4 & 1 & - & - \\
Post-burial & & & & \\
$\quad$ Emergence & - & - & 15 & - \\
$\quad$ Drift & - & - & 4 & - \\
$\quad$ Subsurface search & - & - & 22 & 4 \\
No movement & 1 & - & - & 5 \\
\hline
\end{tabular}

outside of the sediment core, or remained in the pipette and so excluded themselves from statistical analyses.

Burial of $M$. liliana juveniles was rapid throughout the experiment irrespective of treatment (Fig. 3). On average more than 70 (C, CTS, DTS) and $60 \%$ (D) of the juveniles buried within the first minute. After three minutes, more than 77 (C, CTS, DTS) and $60 \%$ (D) had buried (immediate burial, Table 4). The bulk of the remaining individuals exhibited delayed burial so that by the end of $10 \mathrm{~min}$ more than 90 (C, CTS, DTS) and $80 \%$ (D) had entered the sediment. We observed delayed search and burial only in treatments C and CTS.

Logistic regression analyses of those juvenile counts taken $10 \mathrm{~min}$ after the start of the experiment revealed that the 
application of a TS deposit did not decrease but significantly increased the probability of burial of juvenile M. liliana $(p<0.01)$. Furthermore, the probability of burial into intertidal sediment was significantly higher than that into depleted sediment irrespective of treatment (one-sided $p$ value of 0.01025). Because juvenile counts after $4 \mathrm{~h}$ included individuals that had emerged from the sediment and excluded individuals that had drifted away from the sediment (D only, Table 4), we did not attempt any logistic regression analysis at this time interval.

Post-burial behaviours occurred more frequently in D and DTS treatments. Specifically D treatments exhibited emergence and drift (19 individuals). Also, in treatments $\mathrm{C}$ and DTS, respectively, one and five individuals did not move after placement over the course of the experiment. Interestingly, we observed subsurface search, which is crawling below the TS deposit, in depleted sediment (DTS and D) but not in intertidal sediment (C, CTS) confirming that juveniles preferred intertidal sediment over depleted sediment (Table 4).

\section{Discussion}

Cummings et al. (2009) demonstrated that millimetre-thin deposits of TS over defaunated intertidal sediment negatively affect the burial of post-settlement juvenile Macomona liliana and suggested that the juveniles are responding to reduced solutes diffusing from the deposit-underlying sediment but not to contact with the TS deposit. We deposited TS over intact, bioturbated sediment and sediment from which we had removed organic matter by combustion and failed to demonstrate a negative effect of TS on juvenile burial. This result supports evidence from Cummings et al. (2009) that rejection of a TS-covered sediment by the juveniles is not due to their contact with the deposit. It also raises the question of the roles of the resident macrofauna and sediment organic matter content in the juveniles' response to TS deposition an interesting challenge for future experiments.

\subsection{Behavioural response}

For a juvenile bivalve, a primary prey for a large spectrum of bottom feeders including shore birds, demersal fish, shrimp, crabs, polychaetes, nemertines and other predators, burial is an important component of survival and therefore is likely to dominate the initial response irrespective of sediment quality or the presence or absence of a TS deposit. The quality of the sediment did, however, affect this behaviour. Firstly, we showed that our juvenile recruits favoured intact intertidal sediment over sediment from which we had removed living and dead organic matter. This observation aligns with prior studies, which demonstrated rejection of "burnt" and defaunated sand by juvenile M. liliana (e.g., Cummings et al., 1993; Lundquist et al., 2004). The small difference in the particle size distribution between depleted and intertidal sed- iment may have contributed to this result but many other potential causes exist, e.g., lack of cues indicating the presence of suitable food (Nilsson et al., 2000; Stocks and Grassle, 2001), microorganisms (Sebesvari et al., 2006), microbial biofilms (Keough et al., 1995, Van Colen et al., 2009) or other fauna (Woodin, 1985; Woodin et al., 1993; Cummings et al., 1996; Olivier et al., 1996; Dahms et al., 2004).

Secondly, we observed the three modes of post-burial behaviour - subsurface crawling, emergence and drift - only in D and DTS, the treatments that used depleted sediment. This suggests that, although burial is the primary initial response, behaviour promoting dispersal will become important if the juveniles find their substrate unsuitable. In the intertidal sediment, strong bottom currents can initiate sediment movement and transport juveniles independent of behaviour (Roegner et al., 1995; Lundquist et al., 2004). In our experiment, however, we observed juveniles resting on depleted sediment (or emerging if they initially buried) at a seawater flow less than that required to mobilise particles. These individuals chose to leave the experimental sediment: they positioned their shells vertically and produced byssal threads to increase drag promoting uptake and transport by the flume current. Interestingly, most individuals that searched below the surface of the sediment, emerged from the sediment, or drifted away did so on bare depleted sediment (D, Table 4) and only few showed this behaviour on TS-covered (DTS) sediment. Perhaps the presence of a TS deposit changed the bivalves' perception of their environment. Our profiling measurements revealed that the thin TS deposits consumed on average about twice as much $\mathrm{O}_{2}$ than their underlying depleted sediments. This consumption may reflect microbial activity inside the deposit that could have rendered the substrate acceptable for the juveniles. This concept of TS-associated microorganisms mediating the suitability of our DTS treatment would comply with the induction of larval settlement by microbial films on hard substrates where both small organic metabolites (Fitt et al., 1990; Taniguchi et al., 1994; Harder et al., 2002) and macromolecular extracellular polymers provide cues (Maki et al., 1990; Szewzyk et al., 1991; Lau et al., 2003; Lam et al., 2005). Such microbial communities have been intensively investigated and have shown to elicit a specific larval response with respect to their origin and/or growth phase (Wieczorek and Todd, 1997; Qian et al., 2003; Lau et al., 2005).

If in fact the presence of microorganisms in the TS deposit rendered the DTS treatment suitable for juveniles, then perhaps the microbial community of diatoms, cyanobacteria, fungi, and protozoa in the intact intertidal sediment (C) also provided cues to the juveniles. If so, then an understanding of the succession following disturbance of this community by TS deposits will become important. In our experiment, quantification of this community was only possible against the bright background of the TS deposit overlying the intertidal sediment (CTS). Images of this surface revealed that some phototrophic microbiota migrated to the surface within 30 min of TS deposition indicating that this succession is 
rapid and probably faster than reworking of the deposit by the resident fauna.

\subsection{Effects on pore-water solutes}

We showed how TS deposits affect the pore-water distribution of $\mathrm{O}_{2}$ and hydrogen ions, two integrative variables of sedimentary reactions readily accessible at the micrometre scale. An increase in the diffusive distance between solute source and sink either side of the visible sediment-water interface provides one explanation for the observed changes in the distribution of these solutes. For $\mathrm{O}_{2}$, diffusing from seawater across the DBL into the intertidal sediment, the addition of the TS deposit caused significantly lower penetration into the underlying sediment (Table 3, Fig. 2). For hydrogen ions, diffusing from the sediment into seawater, the TS addition increased their concentration in the sediment, that is, it lowered the sediment $\mathrm{pH}$.

The consumption of $\mathrm{O}_{2}$ in the TS-deposit-underlying sediment (CTS) caused an $\left[\mathrm{O}_{2}\right]$ gradient in the DBL above the deposit that was less steep than that in the DBL of the untreated intertidal sediment (C). Assuming that these gradients were stable over time, we used them to estimate the sediments' DOU and found that the deposition of TS must have decreased the DOU, that is, the diffusive uptake of $\mathrm{O}_{2}$ across the visible sediment surface. For organically enriched sediments, one would expect the $\mathrm{O}_{2}$ consumption of the sediment to remain largely unchanged because a decrease in the contribution to the overall $\mathrm{O}_{2}$ demand of aerobic organic matter degradation pathways (lower $\mathrm{O}_{2}$ penetration) may be accounted for by an increase in such contribution of anaerobic degradation pathways through oxidation of reduced substances. This enhanced oxidation can also contribute to the observed decrease in the subsurface $\mathrm{pH}$.

Did the $\left[\mathrm{O}_{2}\right]$ gradient in the DBL of the TS deposit (CTS) represent steady state or transient redox conditions? Transient redox conditions must have existed during and shortly after application of the TS deposit because settling particles disturbed the DBL and polychaetes briefly stopped pumping seawater through their burrows. (The numerous holes in the deposit that appeared shortly after the addition of the TS deposit suggest that polychaetes quickly cleared their burrow openings to re-establish seawater flow through their burrow.) More than $18 \mathrm{~h}$ after application of the TS, however, the distribution of $\mathrm{O}_{2}$ was likely steady, which was confirmed by time series $\mathrm{O}_{2}$ measurements in sediment from our sampling site (unpublished data). These measurements, which were conducted with planar optodes under similar conditions of unidirectional flume flow, demonstrated that disturbance of the DBL by settling TS particles briefly increased the $\mathrm{O}_{2}$ penetration (minutes) into this sediment followed by a gradual upwards shift of the $\left[\mathrm{O}_{2}\right]$ gradient. This shift was completed within $2-3 \mathrm{~h}$ and the resulting $\mathrm{O}_{2}$ distribution did not change in the following hours with the exception of brief and local fluctuations due to sporadic bouts of bioturbation where animals moved anoxic sediment while relocating their burrows.

A decrease in both the oxygenation and the $\mathrm{pH}$ of the deposit-underlying sediment were also reported by Cummings et al. (2009); however, the biogeochemical properties of their intertidal sediment fundamentally differed from that of the intertidal sediment used in our study. Their sediment was frozen, thawed, and washed to remove macrofauna (and organic particulates). This treatment introduced two effects: firstly, it decreased the size of the area for the exchange of solutes between sediment and overlying seawater to the size of the visible sediment surface because burrow-dwelling macrofauna were excluded. Such decrease made subsurface accumulation and diffusion of reduced solutes across the visible sediment surface more likely. Secondly, it will have mixed throughout the sediment reduced solids that, in the uppermost oxygenated layer, may have slowly oxidised leading to transient redox conditions (see, e.g., Vopel et al., 2009) and depression of the pore-water $\mathrm{pH}$. We excluded both effects in our experiment; the natural stratification of our intertidal sediment was intact and the sediment was inhabited by numerous polychaetes maintaining a seawater flow through their burrows. Depending on the spacing of burrows and the diffusive properties of their walls, the resulting solute exchange, which is less affected by the deposition of TS than the visible sediment surface, can effectively control diagenetic reactions and pore-water solute concentrations in the upper sediment layer (Aller and Aller, 1998). In addition to this subsurface exchange, $M$. liliana recruits moving horizontally at the surface of the TS-underling sediment rework the TS deposit an effect also observed by Cummings et al. (2009). Eventually this activity and the activity of the resident macrofaunal community will work the fine particles of the TS deposit into the upper sediment layer and so gradually diminish its effect on the sediment-seawater solute exchange.

Consistent with Cummings et al. (2009), addition of a TS deposit lowered the $\mathrm{pH}$ of the sediment pore water. Such increase in the concentration of hydrogen ions may affect recruitment because it can lower the saturation of the sediment with respect to calcite and/or aragonite and so cause dissolution mortality of shell-bearing, newly settled invertebrates (Green et al., 1998, 2004, 2009). We identified three effects that may lower the pore-water $\mathrm{pH}$ after deposition of freshly suspended TS particles - one immediate effect of the newly formed deposit and two effects resulting from interaction of the deposit with the underlying sediment. With their time-series measurements, Cummings et al. (2009) already demonstrated the immediate effect on pore-water $\mathrm{pH}$ : the settling TS particles form a deposit of low pH (see Fig. 1c in Cummings et al., 2009) that, by diffusion of hydrogen ions, lowers the $\mathrm{pH}$ of the underlying intertidal sediment. Over time (minutes to hours), the diffusive release of hydrogen ions from this deposit removed the concentration gradient until the $\mathrm{pH}$ of this deposit reached that of the overlying seawater. Our measurements $18 \mathrm{~h}$ after the deposition of 
TS and the measurements by Cummings et al. (2009) $14 \mathrm{~h}$ after the deposition of TS suggest that, following these initial changes, other mechanisms can acidify the pore water of the TS-deposit-underlying intertidal sediment. Firstly, as discussed above, the TS deposit impedes the diffusion of hydrogen ions from their source in the underlying intertidal sediment - marked by a characteristic concentration peak (Fig. 2; see Jourabchi et al., 2005) - into the bottom seawater and so increases pore-water concentrations. Secondly, an increasing contribution of anaerobic pathways to the microbial degradation of organic matter may increase the rate of hydrogen ion production via oxidation of reduced substances. Assuming that the measured $\left[\mathrm{O}_{2}\right]$ gradients in the DBL of the CTS and $\mathrm{C}$ treatment represent steady state conditions, the latter effect seems less important in our sediment because there was no evidence for enhanced oxidation of reduced substances.

\subsection{Where to from here?}

Because the factorial design of our experiment does not allow discriminating between effects of the absence of organic matter vs. the interference effect from bioturbation our experiment remains inconclusive with respect to the mechanisms underlying reduced burial rates observed by Cummings et al. (2009). Clearly, inclusion of a treatment that removes fauna from intact sediment without modifying the stratification and composition of the sediment may shed light on the role of, e.g., burrow-dwelling polychaetes in the biogeochemical response of the sediment and behavioural response of recruits to TS deposition. Such treatment would allow us to investigate if subsurface solute exchange mediates the effect of the TS deposits' diffusive impedance on solute reaction and transport in the deposit-underlying sediment - one potential mechanism linking the behaviour of recruits at the surface of the sediment with that of resident burrow-dwelling fauna. If so, then the effect of millimetre-thin TS deposits on the burial behaviour of post-settlement $M$. liliana juveniles becomes a function of the disturbance history of the sediment, that is, the structure of the resident macrofaunal community and its ability to control a large share of the overall sediment-seawater solute exchange. Such ability would have limits that future studies may explore to understand thresholds in the response of intertidal sandflat ecosystems to the deposition of TS.
Acknowledgements. We thank P. M. J. Herman, J. Middelburg, and two anonymous reviewers for their constructive criticism. The New Zealand Ministry of Science and Innovation and the Faculty of Health and Environmental Science of Auckland University of Technology funded this research, respectively, through a $\mathrm{Te}$ Tipu Putaiao Fellowship (TTP AITX1001) and a postgraduate fee scholarship to A. Hohaia. All authors contributed intellectually to this work and the preparation of the manuscript. A. Hohaia and K. Vopel collected specimens and data, conducted the experiment, and analysed data. C. A. Pilditch hosted and supported the laboratory work and specimen collection in the field.

Edited by: J. Middelburg

\section{References}

Aller, R. C. and Aller J. Y.: The effect of biogenic irrigation intensity and solute exchange on diagenetic reaction rates in marine sediments, J. Mar. Res., 56, 905-936, 1998.

Cummings, V. J. and Thrush, S. F.: Behavioural response of juvenile bivalves to terrestrial sediment deposits: implications for postdisturbance recolonisation, Mar. Ecol. Prog. Ser., 278, 179-191, 2004.

Cummings, V. J., Pridmore, R. D., Thrush, S. F., and Hewitt, J. E.: Emergence and floating behaviours of post-settlement juveniles of Macomona liliana (Bivalvia: Tellinacea), Mar. Behav. Physiol., 24, 25-32, 1993.

Cummings, V. J., Pridmore, R. D., Thrush, S. F., and Hewitt, J. E.: Effect of the spionid polychaete Boccardia syrtis on the distribution and survival of juvenile Macomona liliana (Bivalvia: Tellinacea), Mar. Biol., 126, 91-98, 1996.

Cummings, V. J., Vopel, K., and Thrush, S.: Terrigenous deposits in coastal marine habitats: Influences on sediment geochemistry and behaviour of post-settlement bivalves, Mar. Ecol. Prog. Ser., 383, 173-185, 2009.

Cummings, V., Thrush, S., Hewitt, J., Norkko, A., and Pickmere, S.: Terrestrial deposits on intertidal sandflats: sediment characteristics as indicators of habitat suitability for recolonising macrofauna, Mar. Ecol. Prog. Ser., 253, 39-54, 2003.

Dahms, H.-U., Harder, T., and Qian, P.-Y.: Effect of meiofauna on macrofauna recruitment: settlement inhibition of the polychaete Hydroides elegans by the harpacticoid copepod Tisbe japonica, J. Exp. Mar. Biol. Ecol., 311, 47-61, 2004.

Dayton, P. K., Mordida, B. J., and Bacon, F.: Polar marine communities, Am. Zool., 34, 90-99, 1994.

Fitt, W. K., Coon, S. L., Walch, M., Weiner, R. M., Colwell, R. R., Bonar, D. B.: Settlement behavior and metamorphosis of oyster larvae (Crassostrea gigas) in response to bacterial supernatants, Mar. Biol., 106, 389-394, 1990.

Giere, O.: Meiobenthology: The microscopic fauna in aquatic sediments, Springer-Verlag, Germany, 1993.

Green, M. A., Aller, R. C., and Aller, J. Y.: The influence of carbonate dissolution on the survival of shell-bearing meiobenthos in nearshore sediments, Limnol. Oceanogr., 43, 18-28, 1998.

Green, M. A., Jones, M. E., Boudreau, C. L., Moore, R. L., and Westman, B. A.: Dissolution mortality of juvenile bivalves in coastal marine deposits, Limnol. Oceangr., 49, 727-734, 2004. 
Green, M. D., Waldbusser, G. G., Reilly, S. L., Emerson, K., and O'Donnell, S.: Death by dissolution: Sediment saturation state as a mortality factor for juvenile bivalves, Limnol. Oceangr., 54, 1037-1047, 2009.

Harder, T., Lam, C., Qian, P. Y.: Induction of larval settlement in the polychaete Hydroides elegans by marine biofilms: an investigation of monospecific diatom films as settlement cues, Mar. Ecol. Prog. Ser., 229, 105-112, 2002.

Jourabchi, P., Van Cappellen, P., and Regnier, P.: Quantitative interpretation of $\mathrm{pH}$ distributions in aquatic sediments: A reactiontransport modeling approach, Am. J. Sci., 305, 919-956, 2005.

Keough, M. J. and Raimondi, P. T.: Responses of settling invertebrate larvae to bioorganic films: effects of different types of films, J. Exp. Mar. Biol. Ecol., 185, 235-253, 1995.

Lam, C., Harder, T., Qian, P. Y.: Induction of larval settlement in the polychaete Hydroides elegans by extracellular polymers of benthic diatoms, Mar. Ecol. Prog. Ser., 286, 145-154, 2005.

Lau, S. C. K., Harder, T., Qian, P. Y.: Induction of larval settlement in the serpulid polychaete Hydroides elegans (Haswell) : role of bacterial extracellular polymers, Biofouling, 19, 197-204, 2003.

Lau, S. C. K., Thiyagarajan, V., Cheung, S. C. K., Qian, P. Y.: Roles of bacterial community composition in biofilms as a mediator for larval settlement of three marine invertebrates, Aquat. Microb. Ecol., 38, 41-51, 2005.

Lelieveld, S. D., Pilditch, C. A., and Green, M. O.: Effects of deposit-feeding bivalve (Macomona liliana) density on intertidal sediment stability, N. Z. J. Mar. Freshw. Res., 38, 115-128, 2004.

Lohrer, A. M., Thrush, S. F., Hewitt, J. E., Berkenbusch, K., Ahrens, M., and Cummings V. J.: Terrestrially derived sediment: response of marine macrobenthic communities to thin terrigenous deposits, Mar. Ecol. Prog. Ser., 273, 121-138, 2004.

Lundquist, C. J., Pilditch, C. A., and Cummings, V. J.: Behaviour controls post-settlement dispersal by the juvenile bivalves Austrovenus stutchburyi and Macomona liliana, J. Exp. Mar. Biol. Ecol., 306, 51-74, 2004.

Maki, J. S., Rittschof, D., Samuelsson, M.-O., Szewzyk, U., Yule, A. B., Kjelleberg, S., Costlow, J. D., Mitchell, R.: Effect of marine bacteria and their exopolymers on the attachment of barnacle cypris larvae, Bull. Mar. Sci., 46, 499-511, 1990.

Marinelli, R. L. and Woodin, S. A.: Disturbance and recruitment: a test of solute and substrate specificity using Mercenaria mercenaria and Capitella sp. 1, Mar. Ecol. Prog. Ser. 269, 209-221, 2004.

Marinelli, R. L. and Woodin, S. A.: Experimental evidence for linkages between infaunal recruitment, disturbance, and sediment surface chemistry, Limnol. Oceanogr., 47, 221-229, 2002.

Milliman, J. D. and Meade, R. H.: World-wide delivery of river sediment to the oceans, J. Geol., 91, 1-21, 1983.

Nilsson, P. G., Levinton, J. S., and Kurdziel, J. P.: Migration of a marine oligochaete: induction of dispersal and microhabitat choice, Mar. Ecol. Prog. Ser., 207, 89-96, 2000.

Norkko, A., Cummings, V. J., Thrush, S. F., Hewitt, J. E., and Hume, T.: Local dispersal of juvenile bivalves: implications for sandflat biology, Mar. Ecol. Prog. Ser., 212, 131-144, 2001.

Norkko, A., Thrush, S. F., Hewitt, J. E., Cummings, V. J., Norkko, J., Ellis, J. I., Funnell, G. A., Schultz, D., and MacDonald, I.: Smothering of estuarine sandflats by terrigenous clay: the role of wind-wave disturbance and bioturbation in site-dependent macrofaunal recovery, Mar. Ecol. Prog. Ser., 234, 23-41, 2002.
Olivier, F., Desroy, N., and Retiere, C.: Habitat selection and adult-recruit interactions in Pectinaria koreni (Malmgren) (annelida: polychaeta) post-larval populations: results of flume experiments, J. Mar. Res., 36, 217-226, 1996.

Petuha, E. T., Lundquist, C., Pilditch, C. A.: Estimating spatial scale of post-settlement transport potential of Macomona liliana on an intertidal sandflat. N. Z. J. Mar. Freshw. Res., 40, 487-502, 2006.

Pratt, D. R., Pilditch, C. A., Lohrer, D., and Thrush, S. F.: The effects of short-term increases in turbidity on sandflat microphytobenthic productivity and nutrient fluxes, J. Sea Res., doi:10.1016/j.seares.2013.07.009, 2013.

Qian P. Y., Thiyagarajan, V., Lau, S. C. K., and Cheung, S. C. K.: Relationship between bacterial community profile in biofilm and attachment of the acorn barnacle Balanus amphitrite. Aquat. Microb. Ecol., 33, 225-237, 2003.

Roegener, C., Andre, C., Lindegarth, M., Eckman, J. E., and Grant, J.: Transport of recently settled soft shell clams (Mya arenaria L.) in laboratory flume flow, J. Exp. Mar. Biol. Ecol., 187, 1326, 1995.

Roper, D. S. and Hickey, C. W.: Behavioural responses of the marine bivalve Macomona liliana exposed to copper- and chlordane-dosed sediments, Mar. Biol., 118, 673-680, 1994.

Sebesvari, Z., Esser, F., Harder, T.: Sediment-associated cues for larval settlement of the infaunal spionid polychaetes Polydora comuta and Streblospio benedicti, J. Exp. Mar. Biol. Ecol., 337, 109-120, 2006.

Shanks, A. L.: Pelagic larval duration and dispersal distance revisited, Biol. Bull., 216, 373-385, 2009.

Stocks, K. I. and Grassle, J. F.: Effects of microalgae and food limitation on the recolonization of benthic macrofauna into in situ saltmarsh-pond mesocosms, Mar. Ecol. Prog. Ser., 221, 93-104, 2001.

Szewzyk, U., Holmström, C., Wrangstadh, M., Samuelsson, M.-O., Maki, J. S., Kjelleberg, S.: Relevance of exopolysaccharide of marine Pseudomonas sp. Strain S9 for the attachment of Ciona intestinalis larvae, Mar. Ecol. Prog. Ser., 75, 259-265, 1991.

Taniguchi, K., Kurata, K., Maruzoi, T., Suzuki, M.: Dibromomethane, a chemical inducer of larval settlement and metamorphosis of the sea urchin Strongylocentrotus nudus, Fish. Sci., 60, 795-796, 1994.

Thrush, S. F., Hewitt, J. E., Cummings, V. J., Ellis, J. I., Hatton, C., Lohrer, A. M., and Norkko, A.: Muddy waters: elevating sediment input to coastal and estuarine habitats, Front. Ecol. Env., 2, 299-306, 2004.

Thrush, S. F., Hewitt, J. E., Norkko, A., Nicholls, P. E., Funnell, G. A., and Ellis, J. I.: Habitat change in estuaries: predicting broadscale responses of intertidal macrofauna to sediment mud content, Mar. Ecol. Prog. Ser., 263, 101-112, 2003.

Valanko, S., Norkko, A., and Norrko, J.: Rates of post-larval bedload transport in a non-tidal soft sediment system, Mar. Ecol. Prog. Ser., 419, 145-163, 2010.

Van Colen, C., Lenoir, J., De Backer A., Vanelslander, B., Vincx, M., Degraer, S., and Ysebaert, T.: Settlement of Macoma balthica larvae in response to benthic diatom films, Mar. Biol., 156, 2161-2171, 2009.

Vopel, K., Pilditch, C. A., Wilson, P., and Ellwood, M. J.: Oxidation of surface sediment: effects of disturbance depth and seawater flow speed, Mar. Ecol. Prog. Ser., 392, 43-55, 2009. 
Wieczorek, S. K. and Todd, C. D.: Inhibition and facilitation of bryozoan and ascidian settlement by natural multi-species biofilms: effects of film age and the roles of active and passive larval attachment, Mar. Biol., 128, 463-473, 1997.

Woodin, S. A., Lindsay, S. M., and Wethey, D. S.: Process-specific recruitment cues in marine sedimentary systems, Biol. Bull., 189, 49-58, 1995.

Woodin, S. A., Marinelli, R. L., and Lincoln, D. E.: Allelochemical inhibition of recruitment in a sedimentary assemblage, J. Chem. Ecol., 19, 517-529, 1993.
Woodin, S. A., Wethey, D. S., Hewitt, J. E., and Thrush, S. F.: Smallscale terrestrial clay deposits on intertidal sandflats: behavioral changes and productivity reduction, J. Exp. Mar. Biol. Ecol., 413, 184-191, 2012.

Woodin, S. A.: Effects of defecation by arenicolid polychaete adults on spionid polychaete juveniles in field experiments: selective settlement or differential mortality, J. Exp. Mar. Biol. Ecol., 87, 119-132, 1985.

Woodin, S. A.: Process-specific cues for recruitment in sedimentary environments: geochemical signals?, J. Mar. Res., 56, 535-558, 1998. 